\title{
Explaining Myanmar's regime transition: the periphery is central
}

Lee Jones, Senior Lecturer in International Politics, Queen Mary University of London, UK, 1.c.jones@qmul.ac.uk

Date received: 13 August 2013; final version received: 5 November 2013.

\begin{abstract}
In 2010, Myanmar (Burma) held its first elections after 22 years of direct military rule. Few compelling explanations for this regime transition have emerged. This article critiques popular accounts and potential explanations generated by theories of authoritarian 'regime breakdown' and 'regime maintenance'. It returns instead to the classical literature on military intervention and withdrawal. Military regimes, when not terminated by internal factionalism or external unrest, typically liberalise once they feel they have sufficiently addressed the crises that prompted their seizure of power. This was the case in Myanmar. The military intervened for fear that political unrest and ethnic-minority separatist insurgencies would destroy Myanmar's always-fragile territorial integrity and sovereignty. Far from suddenly liberalising in 2010, the regime sought to create a 'disciplined democracy' to safeguard its preferred social and political order twice before, but was thwarted by societal opposition. Its success in 2010 stemmed from a strategy of coercive state-building and economic incorporation via 'ceasefire capitalism', which weakened and co-opted much of the opposition. Having altered the balance of forces in its favour, the regime felt sufficiently confident to impose its preferred settlement. However, the transition neither reflected total 'victory' for the military nor secured a genuine or lasting peace.
\end{abstract}

Key words: Myanmar, Burma, liberalisation, ethnic conflict, political economy, state-building, sanctions

\section{Introduction ${ }^{1}$}

\footnotetext{
${ }^{1}$ Research for this article was financed by an Economic and Social Research Council grant (RES-061-25-0500) for a project entitled 'How Do Economic Sanctions (Not) Work?' I am very grateful to Zaw Nay Aung, Kyaw Thu Mya Han and Aula Hariri for excellent research assistance. This article was originally presented as a paper
} 
In 2010, Myanmar held its first elections since 1990, formally ending a 22-year military dictatorship. ${ }^{2}$ Although some small opposition parties participated, Aung San Suu Kyi's National League for Democracy (NLD) boycotted the polls. Unsurprisingly, the Union Solidarity and Development Party (USDP) - backed by the Tatmadaw (Defence Services) and dominated by ex-military personnel - swept the board. Under the 2008 constitution, largely drafted by the military then approved through a stage-managed referendum, serving military officers also took a quarter of all parliamentary seats. Most observers dismissed the election as a rather irrelevant attempt to disguise continued military dictatorship: modest 'liberalisation' at best. ${ }^{3}$ Subsequently, however, the civilianised administration of President Thein Sein, a former general and prime minister under the military junta, surprised many. The government unleashed extensive economic reforms; legalised political protests and trade unions; lifted media and internet restrictions; released most political prisoners; and incorporated some civil society groups and even former opponents into advisory bodies. The NLD won 43 seats in bye-elections held in 2012, enabling Aung San Suu Kyi to enter parliament and assume a leading role in legislative committees, including one established to revise the constitution. These remarkable developments led Western states to abandon most economic sanctions imposed on Myanmar. Many now take the regime transition more seriously and seek explanations for it.

Recent literature is better at identifying what does not explain Myanmar's transition than what does. Even leading experts express bafflement, saying it 'is hard to line up reliable evidence behind any particular explanation'. ${ }^{4}$ Several recent articles debunk popular explanations, including the impact of Western sanctions, concern about Chinese influence, or fear of Arab Spring-like unrest, convincingly arguing that the regime moved from a position of strength, not weakness. ${ }^{5}$ Western sanctions had negligible or counterproductive effects. ${ }^{6}$

to a workshop on 'Challenging Inequalities: Contestation and Regime Change in East and Southeast Asia', Murdoch University, Perth, 12-13 July 2013. I am grateful to the workshop participants, particularly Aurel Croissant, Eva Hanson, and Meredith Weiss, and to Democratization's anonymous reviewers, for feedback on earlier drafts.

${ }^{2}$ Burma was renamed Myanmar in 1989. This article uses 'Burma' to refer to the country before this, and 'Myanmar' thereafter.

${ }^{3}$ Marco Bünte, "Burma's Transition to 'Disciplined Democracy': Abdication or Institutionalization of Military Rule?,"(2011), 6-7.

${ }^{4}$ Mary Callahan, "The Generals Loosen Their Grip," Journal of Democracy 23, no. 4 (2012): 125-26; see also Nicholas Farrelly, "Discipline without Democracy: Military Dominance in Post-Colonial Burma," Australian Journal of International Affairs 67, no. 3 (2013): 323.

${ }^{5}$ Morten B. Pedersen, "The Politics of Burma's "Democratic" Transition," Critical Asian Studies 43, no. 1 (2011); Callahan, "The Generals."; Kyaw Yin Hlaing, "Understanding Recent Political Changes in Myanmar," Contemporary Southeast Asia 34, no. 2 (2012); Robert H. Taylor, "Myanmar: From Army Rule to Constiutional 
Although many people doubtlessly suffered under sanctions and military misrule, the regime successfully directed the economy eastwards, distributing booming natural resource export revenues to itself and its supporters. From 1988-2010, Myanmar's gross domestic product increased from $\$ 12.6 \mathrm{bn}$ to $\$ 45.4 \mathrm{bn}$, while imports rose from $\$ 246 \mathrm{~m}$ to $\$ 4.8 \mathrm{bn}$, exports, from $\$ 167 \mathrm{~m}$ to $\$ 8.7 \mathrm{bn}$, and foreign investment, from $\$ 4 \mathrm{~m}$ to $\$ 8.3 \mathrm{bn} .{ }^{7}$ China's growing influence was similarly tolerated as the price of Beijing's massive arms transfers, foreign investment, and diplomatic backing. Despite arousing popular and elite concern, Chinese influence did not suddenly escalate to intolerable levels that could explain an abrupt liberalisation. ${ }^{8}$

Suggestions that the regime feared a popular uprising are also questionable. Having bloodily suppressed pro-democracy protests in 1988, the army imprisoned, repressed and disorganised its leading forces, the NLD and the ' 88 Generation of Students. Despite minor 'hit-and-run' protests in Yangon, democratic opposition was largely quelled, with anti-regime elements fleeing abroad and pursuing opposition through exile NGOs. ${ }^{9}$ Their weakness was symbolised through the '9-9-99' campaign, which failed to initiate a hoped-for mass uprising in 1999. Meanwhile, although ethnic-minority rebellions initially persisted in the borderlands, as the army doubled in size, most signed ceasefires by the mid-1990s. ${ }^{10}$ The only serious post-1988 mass unrest was in 2007, when around 100,000 Buddhist monks demonstrated in major cities against price rises and demanded political change. However, as Zöllner documents, the wider population remained overwhelmingly passive, and the protests were quickly and brutally dispersed. ${ }^{11}$ Growing economic disparity, including that induced by sanctions, had not spurred revolt; instead, as one ethnic-minority leader recalls, "when the people became poorer and poorer, they became more apolitical... because they were only [focused] on their survival'. ${ }^{12}$ Anthropological studies concur that, despite widespread dislike of the regime, the population's general response was depoliticisation, atomisation, mysticism,

Rule?," Asian Affairs 43, no. 2 (2012); Lee Jones, "The Political Economy of Myanmar's Transition," Journal of Contemporary Asia DOI: 10.1080/00472336.2013.764143(2013).

${ }^{6}$ Morten B. Pedersen, Promoting Human Rights in Burma: A Critique of Western Sanctions Policy(Lanham: Rowman and Littlefield, 2008).

${ }^{7}$ IMF, "World Economic and Financial Surveys,"(2011); UNCTAD, "Unctadstat,"(2012).

8 Taylor, "Myanmar: From Army Rule to Constiutional Rule?."

${ }^{9}$ Robert H. Taylor, The State in Myanmar(London: Hurst, 2009).

${ }^{10}$ Martin Smith, State of Strife: The Dynamics of Ethnic Conflict in Burma(Washington, DC: East-West Center, 2007).

${ }^{11}$ Hans-Bernd Zöllner, "Neither Saffron nor Revolution: A Commentated and Documented Chronology of the Monks’ Demonstrations in Myanmar in 2007 and Their Background,"(Berlin2009).

${ }^{12}$ Hla Saw, "Interview with the Author,"(Yangon2012). 
and a focus on daily survival. ${ }^{13}$ In surveys conducted in 2010-2011, only $8 \%$ of respondents were prepared to join political protests, and only 6\% anticipated Arab Spring-style unrest. ${ }^{14}$ Many opposition leaders interviewed confirmed their inability to mobilise serious societal protest. ${ }^{15}$ As one laments: 'the 2007 Saffron Revolution ended in failure. They [the regime] can control the whole country... they have won everything in Myanmar' ${ }^{16}$

Even if these popular explanations contained some truth, their fundamental weakness is an inability to explain earlier attempts to enact regime transition, which preceded the 'triggers' that supposedly account for the 2010 transition. In 1990, elections were held for a constituent assembly, prior to governmental elections. From 1993-1996, the regime convened another constituent assembly, the National Convention (NC). The transition accomplished in 2010 was not sudden, but began in 2003 with the regime's 'roadmap to democracy', which involved reviving the NC from 2004-2007, a constitutional referendum in 2008, and finally holding elections. ${ }^{17}$ These repeated, lengthy moves towards regime transition invalidate explanations based on short-term crises or 'tipping points' reached at the end of the last decade. The 2007 protests, for example, occurred just after the NC's conclusion.

Political science theories of authoritarian 'regime breakdown' also seem unhelpful. The 'breakdown' of military governments - which are generally seen as the most fragile of authoritarian regimes - is usually attributed to threats to the armed forces' coherence arising from intra-military factionalism, which prompts 'soft-liners' to seek pacts with a rising societal opposition, creating a top-down 'transformation'. ${ }^{18}$ However, these factors were absent in Myanmar. Experts consistently observe that the Tatmadaw's impressive coherence only increased over time. Reshuffles in 1997 and major purges during 2004-2005 actually strengthened and centralised the regime, with hard-liners reportedly ascendant. ${ }^{19}$ Moreover, the 'roadmap to democracy' continued its sluggish progress unaffected. Rather than regime

\footnotetext{
${ }^{13}$ Monique Skidmore, Karaoke Fascism: Burma and the Politics of Fear(Philadelphia: University of Pennsylvania Press, 2004); Christina Fink, Living Silence in Burma: Surviving under Military Rule, 2nd ed.(London: Zed Books, 2007).

${ }^{14}$ Kyaw Yin Hlaing, "Understanding Recent Political Changes," 203.

15 e.g. Than Nyein, "Interview with the Author,"(Yangon2012); Han Tha Myint, "Interview with the Author,"(Yangon2012).

${ }^{16}$ Hla Saw, "Interview."

${ }^{17}$ Government of Myanmar, "Prime Minister General Khin Nyunt Clarifies Future Policies and Programmes of State,"(2003).

${ }^{18}$ Guillermo O'Donnell and Philippe C. Schmitter, Transitions from Authoritarian Rule: Tentative Conclusions About Uncertain Democracies(Baltimore: Johns Hopkins University Press, 1986); Samuel P. Huntington, The Third Wave: Democratization in the Late Twentieth Century(Norman: University of Oklahoma Press, 1993), ch.5; Barbara Geddes, "What Do We Know About Democratization after Twenty Years?," Annual Review of Political Science 2(1999).

${ }^{19}$ Bünte, "Burma’s Transition," 19-20; Taylor, "Myanmar: From Army Rule to Constiutional Rule?."; Farrelly, "Discipline without Democracy."
} 
instability forcing 'pacts' with opposition forces, the transition was clearly 'dictated' from a position of strength - a scenario the 'transitions' literature generally neglects .

Alternatively, one might analyse Myanmar's transition as 'regime maintenance', an attempt to sustain authoritarianism by creating institutions that facilitate elite power-sharing or opposition co-optation. ${ }^{20}$ This view is advanced by Praeger Nyein, Bünte and Huang, who depict Myanmar's transition merely as the 'institutionalisation of military dominance'.21 Whilst more persuasive, this perspective does not explain the transition's timing or substance. If the military merely sought to perpetuate its own rule via new institutions, why did it not do so earlier? Since the junta was more coherent and the opposition weaker than ever, why would it need to innovate institutionally? If its leader, Senior General Than Shwe, sought to prolong his rule, why did he and his top brass retire, promoting a younger cohort generationally subordinate to Thein Sein? Furthermore, the extent of Thein Sein's reforms also have also exceeded what the mere institutionalisation of army rule should permit.

Although the Tatmadaw undoubtedly remains powerful, Callahan rightly observes 'a new political fluidity... the military's prerogatives have been shrinking... 2011 and 2012 have seen the armed forces as an institution step back from day-to-day governance'. ${ }^{22}$ Huang admits this seems problematic, suggesting that the army's plans 'backfire[d]' ${ }^{23}$ If this were true, why does the Tatmadaw not simply re-intervene?

Arguably, more reliable guidance is offered by the classical literature on military regimes, which highlight their distinctively temporary nature. A basic axiom for the theories considered above, which are inspired by rational choice theory, is that all leaders 'want to get into office and remain there'. ${ }^{24}$ Accordingly, if a regime relinquishes power, it must either have been forced out by internal factionalism and/or societal opposition ('regime breakdown'), or it has not really stepped aside because the same leaders remain in power, in disguised form ('regime maintenance'). Conversely, earlier scholarship on military regimes argued that they were inherently temporary. Brooker notes: 'historically, the type of dictatorship most likely to relinquish power has been rule by the military... because the

\footnotetext{
${ }^{20}$ E.g. Andreas Schedler, ed. Electoral Authoritarianism(Boulder: Westview Press, 2006); K Gandhi and Adam Przeworski, "Authoritarian Institutions and the Survival of Autocrats," Comparative Political Studies 40, no. 11 (2007); Milan Svolik, The Politics of Authoritarian Rule(New York: Cambridge, 2012).

${ }^{21}$ Susanne Praeger Nyein, "Expanding Military, Shrinking Citizenry and the New Constitution in Burma," Journal of Contemporary Asia 39, no. 4 (2009); Bünte, "Burma’s Transition."; Roger Lee Huang, "Re-Thinking Myanmar's Political Regime: Military Rule in Myanmar and Implications for Current Reforms," Contemporary Politics 19, no. 3 (2013).

${ }^{22}$ Callahan, "The Generals," 120, 27.

${ }^{23}$ Huang, "Re-Thinking Myanmar's Political Regime: Military Rule in Myanmar and Implications for Current Reforms," 12.

${ }^{24}$ Geddes, "What Do We Know About Democratization," 125.
} 
military has often seized power without intending to retain it permanently'. ${ }^{25}$ Military intervention is usually prompted and/or justified by severe social, economic and/or political crisis, and coup leaders typically pledge to restore democracy once the crisis is overcome. ${ }^{26}$ However cynically we treat such pledges, they nonetheless mean that 'military regimes are only really legitimised by their future... [they are,] in essence, transitory. A permanent system of military rule is almost a contradiction in terms'. ${ }^{27}$ Accordingly, Sundhaussen and Finer both found that militaries relinquished power once the motivations and/or societal conditions that prompted and enabled their intervention were reversed and reliable civilian successors were found (see Figure 1). ${ }^{28}$

\begin{tabular}{|l|l|l|}
\hline \multicolumn{3}{|c|}{ Reasons for Military Withdrawal } \\
\hline \multirow{3}{*}{ Motivations } & \multicolumn{1}{|c|}{ Military Dispositions } & \multicolumn{1}{c|}{ Societal Conditions } \\
& $\begin{array}{l}\text { (a) Belief in civilian supremacy. } \\
\text { (b) Loss of self-confidence. }\end{array}$ & $\begin{array}{l}\text { (d) Domestic unrest, producing a } \\
\text { legitimacy crisis, ungovernability } \\
\text { or toppling the regime. } \\
\text { (e) External factors: war, }\end{array}$ \\
& $\begin{array}{l}\text { (f) Internal consensus that } \\
\text { invasion, foreign policy disaster, } \\
\text { withdrawal is appropriate. } \\
\text { Necessary } \\
\text { conditions }\end{array}$ & $\begin{array}{l}\text { (g) Adequate protection of } \\
\text { personal and corporate interests } \\
\text { sanctions. }\end{array}$ \\
\hline $\begin{array}{l}\text { and ideologies under the } \\
\text { successor regime. }\end{array}$ & $\begin{array}{l}\text { (h) Trustworthy civilians exist to } \\
\text { whom power can be transferred. }\end{array}$ \\
\hline
\end{tabular}

\footnotetext{
${ }^{25}$ Paul Brooker, Non-Democratic Regimes, 2nd ed.(Basingstoke: Palgrave Macmillan, 2009), 197, 203, emphasis added.

${ }^{26}$ R.J. May, Stephanie Lawson, and Viberto Selochan, "Introduction: Democracy and the Military in Comparative Perspective," in The Military and Democracy in Asia and the Pacific, ed. R.J. May, Stephanie Lawson, and Viberto Selochan(Canberra: ANU E-Press, 2004), 27.

${ }^{27}$ Alain Rouquié, "Demilitarization and the Institutionalization of Military-Dominated Polities in Latin America," in Transitions from Authoritarian Rule: Comparative Perspectives, ed. Guillermo O'Donnell, Philippe C. Schmitter, and Laurence Whitehead(Baltimore: Johns Hopkins University Press, 1986), 110-11. ${ }^{28}$ Ulf Sundhaussen, "Military Withdrawal from Government Responsibility," Armed Forces and Society 10, no. 4 (1984); S.E. Finer, "The Retreat to the Barracks: Notes on the Practice and the Theory of Military Withdrawal from the Seats of Power," Third World Quarterly 7, no. 1 (1985). For a similar, very recent argument that autocratic regimes more generally liberalise when they have 'the strength to concede' - a significant revision to existing democratisation theories - see Dan Slater and Joseph Wong, "The Strength to Concede: Ruling Parties and Democratization in Developmental Asia," Perspectives on Politics 11, no. 3 (2013).
} 
'Regime breakdown' theories identify only few of the potential reasons for military withdrawal, notably (b) and (d). However, the other reasons, particularly (f)-(h), suggest that, rather than disintegrating internally or being ousted externally, military rulers may voluntarily withdraw, provided that the societal conditions they desire - a given political order and/or the security of their own interests, threats to which had initially prompted their intervention - would prevail under a post-military regime. This explains why military regimes typically labour to 'fix the rules of the game' by disciplining civilians and establishing constrained electoral systems - their most common method of withdrawal. ${ }^{29}$ Achieving this may depend on the absence of factors (a)-(e). The military may not feel an orderly succession can be secured until it controls the internal or external threats that prompted its seizure of power. This seems particularly likely in cases like Myanmar, where the military is sufficiently strong to dictate the timing and means of the transition. In such cases, 'the military withdrawal contains an element of continuity, and represents the accomplishment of the mission invoked to justify the initial intervention' ${ }^{30}$

This approach suggests that the explanation for the Tatmadaw's withdrawal from direct rule lies not, as popular or 'regime breakdown' theories suggest, in internal dissension or external challenges, but rather the diminishment of the 'threats' that initially prompted military intervention, enabling the junta to impose a constrained electoral regime that would contain these 'threats' and safeguard the Tatmadaw's corporate interests. From this perspective, explaining Myanmar's transition involves identifying what prompted military intervention; the regime's political goals and strategies over time; how these were pursued and achieved to a satisfactory level (if not completely); and how this facilitated a top-down transition.

This classical approach amends 'regime maintenance' accounts in two ways. First, it better explains the transition's timing. Since regime transition depends on the regime's ability to curb the challenges that prompted military intervention, its timing and nature is not dictated by incumbent elites alone, but stems from conflict and changing power relations

\footnotetext{
${ }^{29}$ Rouquié, "Demilitarization," 114-21; see also Eric A. Nordlinger, Soldiers in Politics: Military Coups and Governments(Eaglewood Cliffs: Prentice-Hall, 1977), 141; Claude E. Welch, "Military Disengagement from Politics: Paradigms, Processes, or Random Events?," Armed Forces and Society 18, no. 3 (1992); Axel Hadenius and Jan Teorell, "Pathways from Authoritarianism," Journal of Democracy 18, no. 1 (2007).

${ }^{30}$ Rouquié, "Demilitarization," 127.
} 
among multiple societal forces, which must be traced historically and situated within their broader geopolitical and economic context. ${ }^{31}$ The relative success of the regime's post-2003 transition strategy, compared to its less successful strategies in the 1990s, is thus explained by changing regime-opposition dynamics. Secondly, this approach jibes better with the relative 'fluidity' Callahan observes in post-transition Myanmar. Although exploring this period is beyond this article's scope, how we explain the transition carries significant consequences for how we analyse Myanmar's trajectory today. Finer argued that the creation of electoral regimes, however constrained, is a form of 'abdication', not mere regime maintenance, because 'the military have changed their role'. They are 'no longer in the driving seat... Their role is simply to support... rulers whom they trust' ${ }^{32}$ Similarly, Nordlinger argued that by creating electoral processes the military transform from 'rulers' to 'moderators'. ${ }^{33}$ This may explain why Thein Sein's government apparently enjoys some autonomy to pursue innovative policies and reforms, but only within 'red lines' that the Tatmadaw will not allow any government to cross. ${ }^{34}$

The remainder of the article explains Myanmar's transition using this classical approach. The first section identifies the military's reasons for intervention, its goals, and its preferred political outcome. The main stimulant for military intervention in Myanmar has been centre-periphery conflict and the threat of ethnic-minority separatism - a risk exacerbated by the state's near-collapse amidst widespread protests in 1988. Fearing chaos, the Tatmadaw seized power. However, it did not envisage perpetual rule, but instead pursued an orderly transition to civilian rule that would safeguard Myanmar's integrity, restrain civilian political squabbling, contain centrifugal forces, and defend the military's individual and corporate interests. Opposition resistance thwarted the junta's efforts to impose 'disciplined democracy' in the 1990s, but the same basic strategy succeeded in 2010 . The second section explains how the regime achieved this. Through coercive and economic statecraft enabled by transformations in Myanmar's political economy and geopolitical context, the military suppressed the democratic opposition and, most crucially, weakened the ethnic-minority resistance groups using violence and co-optation. Although the regime certainly did not entirely defeat these groups, in 2008 they nonetheless accepted a settlement

\footnotetext{
${ }^{31}$ Kevin Hewison, Richard Robison, and Garry Rodan, "Political Power in Industrialising Capitalist Societies: Theoretical Approaches," in Southeast Asia in the 1990s: Authoritarianism, Democracy and Capitalism, ed. Kevin Hewison, Richard Robison, and Garry Rodan(St Leonards: Allen and Unwin, 1993).

${ }^{32}$ Finer, "Retreat to the Barracks," 18.

${ }^{33}$ Nordlinger, Soldiers in Politics, 22.

${ }^{34}$ Jones, "Political Economy of Myanmar's Transition," 13.
} 
they had 'vetoed' in 1996. It is in this sense that the 'periphery' is central in explaining Myanmar's transition.

\section{The Military Regime's Goals and Strategy}

Despite much emphasis on the struggle between democrats and autocrats after 1988, arguably the most critical axis of socio-political conflict since Burma's independence has been centreperiphery struggles between the central government, dominated by the majority-ethnic Bamar, and ethnic-minority and communist insurgencies located in Burma's borderlands. It is civilian politicians' alleged inability to manage this conflict that has historically prompted military intervention and fostered the Tatmadaw's self-perception as the only reliable guardian of Burma's national survival. This outlook can obviously be criticised as selfserving and cynical, or even ridiculed given the poor record of military governance. However, explaining - not endorsing - the military's intervention and withdrawal from political control requires understanding its perspective, priorities and strategies. It was on this basis that the military seized control in 1988, as widespread protests toppled the sclerotic Burmese Socialist Program Party (BSPP) regime, to avert what it perceived as the threat of national disintegration. However, like other military regimes, the junta did not envisage perpetual rule but pledged to restore democracy. Initially unsure of how to do so, the regime eventually groped towards ensuring an orderly transfer to civilian rule that would safeguard its unitary vision of national stability, and the Tatmadaw's own interests, by promoting a constitutional settlement that 'locked in' these outcomes. Societal opposition thwarted this strategy in the 1990s, but it resumed virtually unchanged with the 2003 'roadmap' to 'disciplined democracy', which eventually succeeded.

Centre-periphery conflict has been endemic in Burma since it gained independence in 1948. Pre-colonial Burma had never been ruled as a coherent entity, and British colonialism had exacerbated existing ethnic divisions by governing Bamar-dominated 'ministerial Burma' directly while ruling through semi-autonomous chiefs in the borderlands, ethnicminority regions that comprise about $40 \%$ of Burma's territory and a third of its population (see Figure 2). In 1945, Bamar nationalists sought rapid decolonisation, but the minorities feared losing their autonomy within a unitary, Bamar-dominated state. Nationalists struck a hasty accord with some minorities at Panglong in 1947, pledging to work towards substantial regional autonomy, and Burma's 1947 constitution permitted minority states to secede after 1957. 


\begin{tabular}{|c|c|}
\hline \multicolumn{2}{|c|}{ Officially-Designated Ethnic Groups in Myanmar } \\
\hline Major Group & $\begin{array}{c}\text { Estimated Proportion of } \\
\text { Population (2000) }\end{array}$ \\
\hline Bamar & 66.9 \\
Chin & 2 \\
Kachin & 1.4 \\
Kayah & 0.4 \\
Karen & 6.2 \\
Mon & 2.6 \\
Rakhine & 4.2 \\
Shan & 10.5 \\
Others & 5.7 \\
\hline
\end{tabular}

Figure $2^{35}$

Militarised civil conflict prevented the consolidation of this fragile bargain. Armed minority-nationalist insurgencies began in western Burma even before independence. Shortly thereafter, the Communist Party of Burma (CPB) launched an insurrection, sparking widespread army mutinies and armed rebellion among the Karens, Karenni, Mon and Pao. ${ }^{36}$ Burma's first democratic government was thus instantly embroiled in centre-periphery conflict. The situation worsened in 1949 when a defeated Guomindang army retreated from China into Shan state, establishing military bases and trafficking opium to finance raids into China, backed by Thailand and the United States. ${ }^{37}$ When the Guomindang eventually withdrew, ethnic-minority rebels seized control of the opium trade, using it alongside gemstone and timber smuggling to finance their insurgencies. With rebels seizing control of virtually all of Burma's borders by the late 1950s, the Bamar-dominated army became central to maintaining the country's integrity, expanding dramatically and assuming extensive statebuilding functions, its power gradually exceeding that of central government agencies. ${ }^{38}$

\footnotetext{
35 Tin Maung Maung Than, "Dreams and Nightmares: State Building and Ethnic Conflict in Myanmar (Burma)," in Ethnic Conflict in Southeast Asia, ed. Kusuma Snitwongse and Scott Thompson, W.(Singapore: ISEAS, 2005), 67.

${ }^{36}$ Smith, State of Strife, 10.

${ }^{37}$ Alfred McCoy, The Politics of Heroin in Southeast Asia(New York: Harper \& Row, 1972).

${ }^{38}$ Mary Callahan, Making Enemies: War and State Building in Burma(Ithaca: Cornell University Press, 2007).
} 
Reflecting these threats to Burma's national integrity and the Tatmadaw's increasingly important role, military officers increasingly perceived civilian leaders as unable to halt the country's disintegration. In 1958, amidst a major split in the ruling party, Prime Minister $\mathrm{U} \mathrm{Nu}$ courted communist participation in the government, prompting coup threats from regional army commanders. Nu was forced aside by a military caretaker government from 1958-1960, which sought unsuccessfully to curtail civilian political opposition and infighting. After 1960, amidst continued civilian power struggles, U Nu courted Bamar support by establishing Buddhism as the state religion, sparking protest from non-Buddhist minorities. Shan, Mon and Rakhine leaders demanded greater regional autonomy, while other minority leaders openly discussed secession. Invoking an unacceptable threat to Burma's national integrity, the army seized power again in $1962 .{ }^{39}$

Like other military regimes, the ruling Revolutionary Council now tried to neutralise the threats that had prompted its intervention, before re-civilianising the government. Viewing civilian politics as fractious and corrupt, the army suppressed all parties and civil society organisations, establishing the BSPP as the sole political party in 1971. When it felt able to control the outcome, the junta consulted on a new constitution, which was adopted via referendum in $1974 .{ }^{40}$ Control was then passed to the military-dominated but nominallycivilian BSPP. However, the transition only exacerbated centre-periphery conflict. The 1974 constitution made no real concessions to ethnic minorities, who soon restarted their insurgencies. The army became locked into an endless series of counter-insurgency campaigns and, having eviscerated all other political forces, developed a powerful selfperception as 'the only national force capable of protecting and safeguarding the nation' ${ }^{41}$

In 1988, when the BSPP regime collapsed amidst widespread anti-government protests in Bamar cities against economic sclerosis, the Tatmadaw bloodily suppressed the uprising, seizing control as the State Law and Order Restoration Council (SLORC). Burma's paranoid and reactionary generals, shaped by decades of centre-periphery conflict, perceived the revolt as a plot between 'internal and external destructionists', ${ }^{42}$ with SLORC's Secretary-1, General Khin Nyunt, arguing that 'the country was on the verge of

\footnotetext{
39 Tin Maung Maung Than, "Dreams and Nightmares," 75.

${ }^{40}$ David I Steinberg, Burma: The State of Myanmar(Washington, DC: Georgetown University Press, 2001), 100.

${ }^{41}$ Curtis Lambrecht, "Oxymoronic Development: The Military as Benefactor in the Border Regions of Burma," in Civilizing the Margins: Southeast Asian Government Policies for the Development of Minorities, ed. Christopher R. Duncan(Ithaca: Cornell University Press, 2004), 153.

${ }^{42}$ Farrelly, "Discipline without Democracy," 317.
} 
disintegration'. ${ }^{43}$ Another senior general similarly stated that the 'local tangential forces' of the Bamar pro-democracy movement were 'secondary' to the primary threat of the borderlands' 'centrifugal forces'. ${ }^{44}$ SLORC's intervention was justified as necessary to extinguish the "“fire of civil war", to prevent irresponsible parties and insurgents 'destroying the state' ${ }^{45}$ Commensurate with this reasoning, SLORC announced it would be guided by three 'national causes': 'non-disintegration of the Union; non-disintegration of national solidarity; and perpetuation of national sovereignty'.

However, like other military regimes, SLORC denied seeking perpetual power but pledged to restore democracy. Shortly after seizing control in September 1988, General Saw Maung insisted SLORC had 'absolutely no desire to hold onto state power for a prolonged period' but would hold 'multiparty general elections' - scheduled for May 1990 - then 'return to the barracks'. ${ }^{46}$ This rapid concession reflected the army's desperate need to pacify Myanmar's highly mobilised opposition forces, amidst the collapse and near-bankruptcy of state institutions. However, reflecting the general trial-and-error evolution of regime strategies, ${ }^{47}$ as the situation stabilised, SLORC realised the risks of a hasty transfer of power and began seeking a new constitutional settlement that would subdue political and separatist conflicts and safeguard corporate Tatmadaw interests. Since the 1974 constitution had failed to maintain order, and had been dissolved by the coup, SLORC argued that transferring power immediately risked creating a weak state that could quickly collapse. Accordingly, in mid-1989, SLORC announced that the 1990 polls were to elect an assembly to draft a new constitution, to be followed by a constitutional election and fresh elections. Insisting on the importance of 'national reconsolidation' and the 'emergence of a new enduring state constitution', SLORC insisted it would maintain order while a charter was drafted 'step by step'. ${ }^{48}$

However, this first attempt to create a successor regime that would safeguard the army's 'national causes' was thwarted by opposition resistance. In 1990, despite widespread repression, the NLD won $60 \%$ of the vote and $81 \%$ of the seats. With Western support, it demanded an immediate transfer of power. SLORC refused, insisting that a suitable

\footnotetext{
43 Asiaweek, "We Restored Order," 17 December 1999.

${ }^{44}$ Koh, Koh Kim Seng, Misunderstood Myanmar: An Introspective Study of a Southeast Asian State in Transition(Singapore: Humanities Press, 2011), 67.

${ }^{45}$ Lambrecht, "Oxymoronic Development," 153.

${ }^{46}$ Derek Tonkin, "The 1990 Elections in Myanmar: Broken Promises or a Failure of Communication?," Contemporary Southeast Asia 29, no. 1 (2007): 38; see also Farrelly, "Discipline without Democracy," 318.

${ }^{47}$ Bob Jessop, State Power: A Strategic-Relational Approach(Cambridge: Polity, 2008).

${ }^{48}$ Tin Maung Maung Than, "Dreams and Nightmares," 66; Tonkin, "1990 Elections," 45-46.
} 
constitution must first be drafted. The NLD proposed simply reviving the 1947 constitution, but since this had enabled ethnic-minority secession, the Tatmadaw refused. The army's hostility deepened when an NLD spokesman suggested Nuremburg-style trials for leading generals, threatening the military's personal and corporate interests. ${ }^{49}$ When the NLD sought to convene the elected parliament, SLORC perceived an attempt to form a parallel government. Arguing this would instigate chaos, it cracked down hard, initiating a twentyyear standoff.

SLORC then groped towards a new strategy for regime transition, albeit with the same basic constitution-referendum-elections sequence. In 1992, the regime convened a National Convention (NC) to draft a new constitution. To avoid a repeat of 1990, it diluted elected representatives with more pliable individuals. Importantly, ethnic-minority delegates also participated. This was enabled by the collapse of the CPB insurgency in 1989, as widespread mutinies splintered its militias along ethnic lines. Several war-weary groups subsequently signed ceasefires with SLORC from 1989-1991. The army was then concentrated against the hold-outs, generating further ceasefires. By 1996, 14 ceasefires had been agreed, covering most major resistance organisations, several of which joined the NC. SLORC's generals now believed that moves to restore democracy in 1990 had been 'premature', and consequently sought an orderly transition to a constrained - 'disciplined', or 'discipline-flourishing' - democracy. ${ }^{50}$ Reflecting SLORC's 'national causes', the regime insisted that the NC be guided by several non-debatable 'basic principles', which sought to constrain Myanmar's centrifugal forces by establishing a strong central state with a leading role for the military in maintaining national integrity (see Figure 3). However, opposition forces again resisted these constraints. The NLD walked out of the NC in 1995 and, more importantly, several ceasefire groups demanded greater autonomy than SLORC dared concede. Lacking the strength to simply impose its will, SLORC had to abandon the NC in 1996. It reorganised itself into the State Peace and Development Council (SPDC) in 1997, settling in for a long haul.

The regime's third attempt at regime transition repeated much the same pattern. The 2003 'roadmap to democracy' involved reconvening the NC to design a 'disciplined democratic system'; the drafting of a new constitution; its adoption via a referendum; elections and the formation of a new government. The SPDC's stated concerns and objectives remained as constant as its unimaginative methods:

\footnotetext{
${ }^{49}$ Tonkin, "1990 Elections," 42, 48.

${ }^{50}$ Koh, Koh Kim Seng, Misunderstood Myanmar, 102-3, 11-2, 41.
} 
since... independence, armed insurrection emerged across the country... result[ing] in the weakening of national unity... Without trying to heal these own injuries and wounds it is very difficult to change overnight into a democratic state... [We must ensure] the emergence of a disciplined democratic system that does not [a]ffect... the Union of the national races... [or] the integrity of our people and nation. ${ }^{51}$

Accordingly, identical constraints were placed on the NC, which reconvened from 20042007, without the NLD (which boycotted proceedings) but with expanded ethnic-minority participation. The roadmap survived the 2005 purge of its architect, General Khin Nyunt, underscoring the regime's consensus on basic strategy. Minority leaders again complained of being ignored and won few concessions. Nonetheless, this time the NC concluded successfully, drafting a constitution virtually identical to that proposed by SLORC in 1993 (see Figure 3). The stage-managed constitutional referendum was held in 2008; elections, in 2010; and power transferred to a civilian administration in 2011, completing the 'roadmap'.

\begin{tabular}{|l|l|}
\hline \multicolumn{2}{|c|}{ Comparison of Constitutional Proposals and Outcome } \\
\hline \multicolumn{1}{|c|}{ 1993-1996 National Convention } & \multicolumn{1}{c|}{ 2008 Constitution } \\
\hline $\begin{array}{l}\text { Aims and Objectives of the State: 'non-disintegration of the } \\
\text { Union; non-disintegration of national solidarity; } \\
\text { perpetuation of sovereignty; flourishing of a genuine } \\
\text { multiparty democracy system; ... justice, liberty and } \\
\text { equality... for the Tatmadaw to be able to participate in the } \\
\text { national political leadership role'. }\end{array}$ & $\begin{array}{l}\text { Idencept an } \\
\text { amendment to 'genuine, } \\
\text { disciplined multi-party } \\
\text { democratic system'. }\end{array}$ \\
\hline $\begin{array}{l}\text { State Structure: Seven Regions (covering predominantly- } \\
\text { Bamar central Myanmar), seven States (predominantly } \\
\text { ethnic-minority states), and six Self-Administered Regions } \\
\text { and zones (special autonomous areas delegated to ceasefire } \\
\text { groups). Authority is highly centralised, with very limited } \\
\text { local autonomy and no right to secession. }\end{array}$ & $\begin{array}{l}\text { Identical, except for a change } \\
\text { in the capital city. }\end{array}$ \\
\hline $\begin{array}{l}\text { Executive: Presidential system. President and Vice- } \\
\text { Presidents to be selected by an electoral college formed }\end{array}$ & $\begin{array}{l}\text { Identical, though executive } \\
\text { responsibilities are further }\end{array}$ \\
\hline
\end{tabular}

${ }^{51}$ Government of Myanmar, "Future Policies and Programmes of State," 12-13, 16. 
from the legislature. Candidates must be born to Myanmar parents; aged at least 45; 'well acquainted' with matters of state, including 'military affairs'; resident in Myanmar for 20 years prior to an election; and they, their spouse and children must 'not owe allegiance to a foreign power' or be foreign citizens.* The president appoints the cabinet, but must select military personnel as ministers and deputy ministers of defence, security/ home affairs and border affairs. The president, vice-president and ministers must resign their seats in the legislature and not participate in party activities.

Legislature: Bicameral national parliament comprising lower house elected on the basis of population, and upper house with equal representation from each region/ state. Regional/ state/ zone parliaments are elected on basis of population. $25 \%$ of seats are reserved for military personnel.

Judiciary: Independent. Hierarchy of supreme court, region/state high courts, and subordinate law courts.

Military: Military affairs are governed 'independently' by the Tatmadaw. During a 'state of emergency characterised by inability to perform executive functions', the President may assert executive powers but the army also 'has the right... to pre-empt that danger and provide protection'. The army is assigned responsibility for 'safeguarding nondisintegration of the Union, non-disintegration of national solidarity and perpetuation of sovereignty' and protecting the Constitution. If these are threatened, the army commander-in-chief 'has the right to take over and exercise state power'. elaborated and they may be dismissed for 'inefficient discharge of duties'. A National Defence and Security Council, comprising executive, legislative and military leaders, is also established to assist the president and assume governmental powers during emergencies.

Identical, except House of Representative constituencies are allocated to townships as well as by population, and parliamentary responsibilities and procedures are elaborated. Identical. Judicial responsibilities are further elaborated; 'judges may be dismissed for inefficient discharge of duties'.

Identical, except for provisions for the National Defence and Security Council to reassume governmental power and restore democracy once the emergency ends; the army commander-in-chief is given vice-presidential status; and military justice is the military's sole domain. 
* These conditions were designed to render Aung San Suu Kyi ineligible.

Fig. 3. ${ }^{52}$

To summarise: the Tatmadaw's predominant concern has been the Union's territorial integrity and political stability, particularly the threat from ethnic separatism. Consequently, although the post-1988 military regime sought to transfer power to civilians, it sought durable safeguards to defend Myanmar's unity and preserve the Tatmadaw's leading role. The regime pursued this goal repeatedly, pressing other societal actors to accept a 'disciplined democracy'. Thus, Myanmar's regime transition in 2010 was not a 'sudden' event requiring short-term explanations, but the culmination of a lengthy struggle. How did the regime succeed in 2010, having failed in 1990 and 1996 ?

\section{Transformations in Political Economy and State-Building in Myanmar, 1988-2010}

The basic answer is that the balance of power between regime and opposition forces shifted fundamentally in the former's favour, enabling it to diminish (though not destroy) the threats that had prompted its intervention and withdraw on its own terms. This outcome stemmed from the transformation of Myanmar's geopolitical and economic context, which supported the regime's strategies to centralise power and reduce centrifugal challenges, giving it the confidence to resume Myanmar's forced march to 'disciplined democracy'.

\section{The Post-Cold War Shift 'from Battlefields to Marketplaces'}

Though rooted in local grievances, Burma's communist and separatist insurgencies were always sustained externally to a significant degree. Throughout the Cold War, neighbouring states aided rebel groups along their borders, providing sanctuary and enabling the transboundary smuggling of drugs, timber, gemstones and weapons that supported the insurgencies. By 1987, this black-market trade had reached an estimated $\$ 3 \mathrm{bn}, 40 \%$ of Burma's GDP. ${ }^{53}$ Defeating the insurgencies was impossible while this trade flourished. A critical change, therefore, was the post-Cold War reorientation of neighbouring states, particularly China and Thailand. As the ideological and material benefits of backing the

\footnotetext{
${ }^{52}$ Sources: New Light of Myanmar, 17 September 1993, 10 April 1994, 11 April 1995, 29 March 1996, 31 March 1996, 1 April 1996; Constitution of the Republic of the Union of Myanmar, 2008.

${ }^{53}$ Smith, State of Strife, 19.
} 
insurgents waned, powerful politico-business elites sought full access to Myanmar's lucrative, largely-untapped natural resources, which required sound government-togovernment relations, not piecemeal smuggling. Consequently, having stopped aiding the CPB in the 1970s, China abandoned it entirely in 1989, instead cultivating ties with SLORC. Thailand also stopped supporting Burma's anti-communist rebels, seeking instead to transform 'battlefields into marketplaces'. ${ }^{54}$ ASEAN likewise pursued 'constructive engagement' with SLORC.

This shift strengthened SLORC against opposition groups in three ways. First, neighbouring states pushed insurgents to sign ceasefires. Second, the state was rescued from near-bankruptcy by an influx of foreign investment and trade deals in logging, fisheries and mining, with rents now flowing to the regime rather than rebels. Foreign investment boomed from $\$ 58 \mathrm{~m}$ in $1990 / 91$ to $\$ 800 \mathrm{~m}$ by $1996 / 7$, much of which went to military-linked firms. ${ }^{55}$ Hardwood timber exports alone earned \$160m annually from 1988-1995. ${ }^{56}$ Thai loggers also built roads through the borderlands, facilitating military penetration. ${ }^{57}$ Third, the regime evaded the Western arms embargo, importing over \$2bn of predominantly-Chinese weaponry with assistance from Singaporean banks. ${ }^{58}$

These developments stabilised the regime, boosted the ceasefire drive, and gave SLORC the confidence to convene the first NC, since 'the conditions for peace and stability improved... [and] national unity had been built to a certain extent' ${ }^{59}$ However, SLORC was still too weak to impose its preferred settlement. The NLD resisted and, more importantly, some key ceasefire groups, like the Kachin Independence Organisation (KIO), boycotted the NC. Others protested the limited autonomy provisions being offered; and still others remained in armed rebellion. The army lacked sufficient strength to impose its preferences without risking renewed armed conflict. How did the Tatmadaw surmount these challenges?

\section{Coercion, Ceasefire Capitalism and Centralisation}

\footnotetext{
${ }^{54}$ Paul Battersby, "Border Politics and the Broader Politics of Thailand's International Relations in the 1990s: From Communism to Capitalism," Pacific Affairs 71, no. 4 (1998-1999).

${ }^{55}$ Steinberg, Burma, 169.

${ }^{56}$ Khin Maung Kyi et al., Economic Development of Burma: A Vision and a Strategy(Stockholm: Olof Palme International Center, 2000), 13.

${ }^{57}$ Battersby, "Border Politics," 486-87.

${ }^{58}$ Andrew Selth, Burma's Secret Military Partners(Canberra: ANU, 2000).

${ }^{59}$ Government of Myanmar, "Future Policies and Programmes of State."
} 
Part of the answer is coercion, enabled by the transformed political economy context. Using newly-available resources, SLORC doubled the army's size and built a powerful military intelligence apparatus that penetrated most opposition groups. ${ }^{60}$ Having already incarcerated many pro-democracy activists, SLORC repressed the NLD after its NC boycott, provoking mass defections and the closure of all its offices outside the capital. By the early 2000s, the pro-democracy movement had largely been 'crushed', with only Western backing enabling its survival. ${ }^{61}$ Military penetration of the borderlands also increased sharply. The expanded army was able to establish garrisons in ceasefire groups' territory, shifting from seasonal counterinsurgency campaigns to permanently hold territory. The regime thereby captured rebel groups' natural resource bases and forcibly relocated their supporters, while the state was enabled to 'tax, monitor and micromanage the populace'. ${ }^{62}$ The Tatmadaw also exploited rebel divisions, co-opting splinter groups to fight their former comrades.

However, also important was the co-optation of borderlands elites and the centralisation of politico-economic power through 'ceasefire capitalism'. Ethnic-minority rebels largely signed ceasefires out of war weariness, poverty and a desire for development. Accordingly, their subsequent incorporation into a national system of rule was primarily pursued through economic means: development spending; joint business ventures; and the rerouting of economic flows to benefit the regime. As one junta leader explains, these strategies sought 'to enhance the centripetal forces holding the country together by... nullify[ing] the centrifugal forces made up of the secession-seeking minority/ national races, insurgents, narcotics groups, and even the straggling communists, by inviting them back to the legal fold'. ${ }^{63}$

The ceasefires established a basic quid pro quo: in exchange for suspending armed struggle, former rebels would receive government development assistance, retain control over some territory and checkpoints, and continue cross-border trading, initially including opium. These pacts converted many ethnic-minority leaders into government 'subcontract[ors]'. ${ }^{64}$ Army outposts, government agencies and NGOs entered the borderlands, extending the state's reach into areas it had never controlled. By 2003, the government spent $\$ 506 \mathrm{~m}$ on

\footnotetext{
${ }^{60}$ Selth, Burma's Secret Military Partners.

${ }^{61}$ Han Tha Myint, "Interview."

${ }^{62}$ Lambrecht, "Oxymoronic Development," 171.

${ }^{63}$ Koh, Koh Kim Seng, Misunderstood Myanmar, 67.

64 Taylor, The State, 450.
} 
borderlands development and social services to promote the 'consolidation of national unity', which was regarded as the 'basic foundation... of [a] democratic system'. ${ }^{65}$

More important was the incorporation of ethnic-minority elites through their participation in capitalist economic development. This took two main forms. First, the regime initiated joint ventures with local elites to exploit the borderlands' natural resources, notably in logging, mining and agriculture, helping 'the regime to expand its military, administrative and economic reach into areas of the country where it previously had little or none' ${ }^{66}$ The army and ceasefire groups' militias guarded these operations, whilst local elites brokered transboundary investments via black market contacts. Foreign trade and overseas investment were again critical in enabling this strategy. Two-thirds of foreign investment went to just three resource-rich minority states. ${ }^{67}$ Export revenues financed patronage networks centred on army regional commanders, who also dispensed resource concessions to local elites who brokered ceasefires. ${ }^{68}$ The alliances formed around extractive industries generated new power structures in the borderlands, which Callahan dubs " "emerging political complexes"... flexible and adaptive networks that link state and other political authorities to domestic and foreign business concerns... traditional indigenous leaders, religious authorities, overseas refugee and diaspora communities, political party leaders, and NGOs. ${ }^{69}$

The second form of economic incorporation involved encouraging borderlands elites to invest their illegally-obtained wealth in the national economy. After paying a $25 \%$ 'whitening' tax, drugs barons and smugglers could launder their money through state-owned banks and invest in 'legitimate' national businesses. Loyal individuals who rendered useful services again received extensive patronage, with borderland kingpins establishing largescale conglomerates, receiving lucrative government contracts, and dominating the emerging private banking sector. ${ }^{70}$

The money-laundering process highlights a crucial aspect of 'ceasefire capitalism': the deliberate re-routing of economic flows to strengthen the central regime and weaken 'centrifugal forces'. Promoting economic development in the borderlands risked

\footnotetext{
${ }^{65}$ Government of Myanmar, "Future Policies and Programmes of State," 11, 13.

${ }^{66}$ Ken MacLean, "Sovereignty in Burma after the Entrepreneurial Turn: Mosaics of Control, Commodified Spaces, and Regulated Violence in Contemporary Burma," in Taking Southeast Asia to Market: Commodities, Nature, and People in the Neoliberal Age, ed. Joseph Nevins and Nancy Lee Peluso(Ithaca: Cornell University Press, 2008), 143.

${ }^{67}$ TNI, Financing Dispossession: China's Opium Substitution Programme in Northern Burma(Amsterdam: TNI, 2011), 12.

${ }^{68}$ US Embassy, "Burma: Jadeland Co. Supporting the Regime,"(Yangon2009).

${ }^{69}$ Mary Callahan, Political Authority in Burma's Ethnic Minority States: Devolution, Occupation and Coexistence(Washington, DC: East-West Center, 2007), 3-4.

${ }^{70}$ Jones, "Political Economy of Myanmar's Transition," 9-10.
} 
strengthening ceasefire groups. To avoid this, the regime increasingly centralised economic flows, making access dependent on loyalty to the state. Thus, mining permits issued to ceasefire groups initially insisted that at least $10 \%$ of their gemstones were sold through government-run auctions in Yangon. ${ }^{71}$ However, by the mid-2000s, all gemstones mined by joint ventures had to be sold in this way, and most exports to China, Myanmar's major market, had been re-routed through Yangon, and later Naypyidaw. ${ }^{72}$ By taking control of valuable jade mines, the Tatmadaw 'shut out' many businesses linked to the KIO, redirecting lucrative rents to itself and its allies. ${ }^{73}$ Similarly, timber exports were redirected from crossborder roads, controlled and 'taxed' by the KIO, to Yangon's port, in order to 'squeeze the KIO out of the timber business and thus weaken their political position against the regime'. ${ }^{74}$ In agribusiness, local elites either joined increasingly centralised networks of army commanders and Chinese investors, or were squeezed out. These strategies 'increased state funds... [and] - more importantly - cut off ethnic political resistance groups' access to resource rents... trading networks became connected to the regime's wider patron-client relations', with power shifting from local headmen to 'regional and national military officials'. ${ }^{75}$ These manoeuvres were supported by development spending on road-building, which facilitated military penetration that helped deprive 'insurgent groups... of their resource base, [and] assert control over the lucrative border trade'. ${ }^{76}$ Although these developments massively empowered regional commanders, the risk that they would establish independent powerbases was countered by appointing them to the SPDC and other national positions . Meanwhile, rising foreign investment in state monopolies like hydropower, oil and gas bolstered the regime, since export rents flowed directly to the state, bypassing the borderlands entirely. Accordingly, from 1990-2005 the estimated ratio of smuggling to official trade fell from 85 to $50 \% .^{77}$

It is important to underscore that this centralising process was contested, uneven and incomplete. Along the Thai border, for example, Sino-Thai rivalry has allowed the United

\footnotetext{
${ }^{71}$ MacLean, "Sovereignty in Burma," 143.

${ }^{72}$ US Embassy, "Mandalay: Diplomatic Views,"(Yangon2006).

73 Andrew R.C. Marshall and Min Zayar Oo, "Myanmar Old Guard Clings to \$8-Billion Jade Empire," Globe and Mail, 4 October 2013.

${ }^{74}$ Kevin Woods, "Conflict Timber Along the China-Burma Border: Connecting the Global Timber Consumer with Violent Extraction Sites," in Chinese Circulations: Capital, Commodities, and Networks in Southeast Asia, ed. Eric Tagliacozzo and Wen-Chin Chang(Durham, NC: Duke University Press, 2011), 489.

75 "Ceasefire Capitalism: Military-Private Partnerships, Resource Concessions and Military-State Building in the Burma-China Borderlands," Journal of Peasant Studies 38, no. 4 (2011): 750-52, 65-67.

${ }^{76}$ Lambrecht, "Oxymoronic Development," 162.

77 Jalal Alamgir, "Myanmar's Foreign Trade and Its Political Consequences," Asian Survey 48, no. 6 (2008): 983.
} 
Wa State Army (UWSA) to retain considerable control over local rents and thereby maintain large militias. ${ }^{78}$ Cross-border smuggling persists, and extractive investments reinforce transnational economic relations, not merely national ones. The gains from development spending and ceasefire capitalism have accrued to narrow elite, while rapacious extractive projects alienated many. Crucially, the SPDC never addressed the minorities' political and cultural grievances. Ceasefires marked the absence of war, not genuine or lasting peace. Despite this, the overall trajectory clearly favoured the regime, reducing many ceasefire group leaders' will and capacity to resume armed struggle. This allowed the SPDC to launch its 'roadmap' to 'disciplined democracy'.

\section{Resuming the Roadmap}

Like other military regimes, the Tatmadaw retreated from direct governmental control once it had sufficiently diminished the challenges that had prompted its intervention, notably ethnicminority insurgencies and pro-democracy forces, and found trustworthy civilian organisations to take over, in the form of the USDP.

The 2003 announcement of the 'roadmap to democracy' reflected the SPDC's growing confidence that insurgent threats, whilst definitely not eliminated, were sufficiently under control to permit a transition to 'disciplined democracy'. SPDC minister General David Abel articulates this explicitly, stating that in the 1990s, 'we didn't have peace in the country... The mechanisms of democracy couldn't work, because we had these insurgencies. Now that the insurgency has almost come to an end, we implemented... the roadmap' ${ }^{79}$ The change in centre-periphery power relations was reflected in the behaviour of ethnic-minority leaders. In the 1990s, some major ceasefire groups had boycotted the NC, some maintained separatist platforms, and others remained in armed rebellion. By 2004, virtually every group had signed a ceasefire, and the last major holdout, the Karen National Union, entered peace talks; all had abandoned separatism to pursue regional autonomy within the Union of Myanmar; and all major groups joined the NC, seeing the roadmap as the 'culmination of their ceasefire strategies', a chance to embed their post-1988 gains. ${ }^{80}$ Despite similar complaints about the limited regional autonomy on offer, in 2007 they approved a

\footnotetext{
78 TNI, Financing Dispossession, 75.

${ }^{79}$ David Abel, "Interview with the Author,"(Yangon2012).

${ }^{80}$ Martin Smith, "Ethnic Participation and National Reconciliation in Myanmar: Challenges in a Transitional Landscape," in Myanmar's Long Road to National Reconciliation, ed. Trevor Wilson(Singapore: ISEAS, 2006), 46.
} 
constitution almost identical to that offered in 1996. The KIO's conduct was emblematic. Having boycotted the 1993-1996 NC, in 2004-2007, they participated. In 2007, while Buddhist monks were marching in Yangon, KIO leaders were attending pro-NC mass rallies, and in 2008 they instructed their followers to vote 'yes' in the constitutional referendum. ${ }^{81}$

The pro-democracy opposition's relative decline was also apparent. In 1995, the NLD boycott had effectively 'vetoed' the NC. In 2004-2007, the much-weakened NLD again boycotted the NC, but the regime proceeded nonetheless. By then the SPDC had created a 'civilian' organisation to which it could transfer power without threatening its 'national causes' or corporate interests: the Union Solidarity and Development Association, a mass organisation claiming 23 million members, which converted into the USDP to contest the 2010 elections. Realising, like the minorities, that the 'roadmap' was the only game in town, many non-NLD opposition politicians also joined the electoral process. The NLD splintered, with the National Democratic Force (NDF) breaking away to participate in the polls. The SPDC thereby successfully bounced the weakened, fragmented opposition into its preferred settlement. As NDF chairman Khin Maung Swe observes, 'without any effort of politicians, or the NLD, or us, the political scenario has changed. It changed only because Than Shwe and his military top brass decided to move' ${ }^{82}$

\section{Conclusions and Implications}

This article argued that Myanmar's regime transition shares many characteristics with other transitions from military rule. Classical treatments of military dictatorships suggest that, assuming they succumb neither to internal factionalism nor external revolt, militaries retreat from direct political control when they feel they have sufficiently addressed the social, political and/or economic crises that prompted their intervention and can install a successor regime that will safeguard the military's preferred socio-political and economic order and protect its corporate interests. In Myanmar, military intervention has been driven by the perceived inability of civilian administrations to manage centre-periphery conflict and ethnicminority separatism. After seizing power in 1988, the army sought to impose a constitutional settlement that would minimise destabilising political rivalries and contain Myanmar's 'centrifugal forces'. However, this plan for 'disciplined democracy' was repeatedly thwarted

\footnotetext{
${ }^{81}$ Mandy Sadan, "Minorities and Political Governance: The Myanmar Situation," in Minorities, Community Rights \& Political Governance: South and Southeast Asian Scenarios, ed. Lipi Ghosh(London: Routledge, 2009), 151, 53.

${ }^{82}$ Khin Maung Swe, "Interview with the Author,"(Yangon2012).
} 
by societal opposition in the 1990s. Subsequently, however, structural geopolitical and economic changes combined with the SPDC's coercive and economic statecraft tipped the balance of forces in its favour. The democratic opposition was repressed, while 'ceasefire capitalism' incorporated and reduced the perceived threat from Myanmar's 'centrifugal forces'. By diminishing the challenges that had prompted military intervention, and reducing effective resistance to its plans, the SPDC was enabled to impose its 'roadmap' to 'disciplined democracy'.

Although these shifting power relations sufficed to allow the regime to liberalise, this does not mean that centre-periphery conflict has ended. Certainly, the state's territorial reach and coercive power are greater than ever, and ethnic minorities now seek a future within, rather than apart from, the Union of Myanmar. Nonetheless, the strategies that enabled these results won the state few allies and precious little affection. Moreover, like most settlements imposed through coercion and elite cooptation, the 2008 constitution failed to address many wider grievances and consequently does not guarantee the peace and stability sought by the SPDC. It does not satisfy the demands of democratic forces, nor does it address the minorities' aspirations for local autonomy, cultural rights, and greater control over natural resource revenues. On the contrary, army brutality, forced displacement, and the rapacious extractive investments and land grabs associated with 'ceasefire capitalism' only fuelled popular resentment among minority populations, even if their leaders had essentially been coopted, neutralising their capacity to resist.

The limits of the SPDC's 'success' were clearly displayed during the transition. In 2009, the regime demanded that ceasefire groups' militias convert into 'border guard forces' (BGFs) under army command as a condition for their participation in the elections, despite earlier agreements that the merger would take place afterwards. Although complaining vociferously, several groups complied. However, others refused, and several ceasefires collapsed. Although the Tatmadaw swiftly suppressed the weaker militias, it struggled against the stronger UWSA and the KIO. Unlike in previous decades, this conflict was now geographically contained, posing no threat to the central government, and consequently did not derail the roadmap. Nonetheless, it apparently created the long delay between the 2008 referendum and the 2010 elections and certainly illustrated the limits of the regime's coercive power. Moreover, the KIO was considerably rejuvenated. Forced to resume armed struggle, the KIO leadership, long alienated from the Kachin masses through its co-optation by the SPDC and participation in 'ceasefire capitalism', suddenly reconnected with its disaffected 
base. This has enabled it to sustain considerable guerrilla resistance against Tatmadaw offensives.

The quest for a more stable settlement in the borderlands has fallen to the Thein Sein administration, which has pursued individual ceasefires ahead of national negotiations - a socalled 'second Panglong'. The government has mooted the possibility of constitutional amendments and 'federalism', historically a threatening notion, has even been floated by one minister. In another unprecedented development, Thein Sein has permitted the involvement of Norway, Japan, China and the United Nations in the peace process. These unusual developments are apparently consistent with Finer and Nordlinger's view that the military's withdrawal from direct control introduces new political dynamics rather than simply representing 'regime maintenance'. Yet, exactly how much latitude the new government enjoys within the Tatmadaw's 'red lines' is unclear. Notwithstanding the reformist commitments of some ministers, the military still controls the ministries of defence and border affairs and remains central to borderlands governance. 'Divide and rule' strategies have been maintained and offensives against the KIO have persisted despite two presidential ceasefire orders, delaying a settlement and displacing around 100,000 people. Despite Thein Sein's reforms, the powerful interests embedded in 'ceasefire capitalism' have also perpetuated its predatory dynamics, generating deepening resentment. ${ }^{83}$ How much the army and other conservative Bamar elites are prepared to concede to the minorities to achieve a genuine political settlement remains unclear. Although some modernisers accept that new strategies are required, the military - including the retired officers leading the USDP - fought for decades to impose its designs, and many may resist. Although military re-intervention in politics remains unlikely while unrest in the borderlands remains geographically contained, any escalation or spread of conflict - including the increasingly violent communal strife between Buddhists and Muslims - will severely escalate the risk. All of Myanmar's political forces, including opposition parties, recognise that they are steering a fine line between promoting reform and provoking a military backlash. Even so, and although Myanmar's armed groups may no longer seriously threaten the state's integrity, the Bamar elite may still need to learn that there can be no lasting peace without justice.

\section{Notes on Contributor}

\footnotetext{
${ }^{83}$ Jones, "Political Economy of Myanmar's Transition."
} 
Lee Jones is senior lecturer in international politics at Queen Mary University of London. His research interests revolve around state-society relations, security, intervention, sovereignty and governance in developing countries, particularly Southeast Asia. He is author of ASEAN, Sovereignty and Intervention in Southeast Asia (2012) as well as articles in International Studies Quarterly, Review of International Studies and other international journals.

\section{References}

Abel, David. "Interview with the Author." Yangon, 2012.

Alamgir, Jalal. "Myanmar's Foreign Trade and Its Political Consequences." Asian Survey 48, no. 6 (November/December, 2008 2008): 977-96.

Asiaweek. "We Restored Order." 17 December 1999.

Battersby, Paul. "Border Politics and the Broader Politics of Thailand's International Relations in the 1990s: From Communism to Capitalism." Pacific Affairs 71, no. 4 (1998-1999): 473-88.

Brooker, Paul. Non-Democratic Regimes. 2nd ed. Basingstoke: Palgrave Macmillan, 2009.

Bünte, Marco. "Burma's Transition to 'Disciplined Democracy': Abdication or Institutionalization of Military Rule?", 2011.

Callahan, Mary. "The Generals Loosen Their Grip." Journal of Democracy 23, no. 4 (2012): 120-31.

Making Enemies: War and State Building in Burma. Ithaca: Cornell University Press, 2007.

-. Political Authority in Burma's Ethnic Minority States: Devolution, Occupation and Coexistence. Washington, DC: East-West Center, 2007.

Farrelly, Nicholas. "Discipline without Democracy: Military Dominance in Post-Colonial Burma." Australian Journal of International Affairs 67, no. 3 (2013): 312-26.

Finer, S.E. "The Retreat to the Barracks: Notes on the Practice and the Theory of Military Withdrawal from the Seats of Power." Third World Quarterly 7, no. 1 (1985): 16-30.

Fink, Christina. Living Silence in Burma: Surviving under Military Rule. 2nd ed. London: Zed Books, 2007.

Gandhi, K, and Adam Przeworski. "Authoritarian Institutions and the Survival of Autocrats." Comparative Political Studies 40, no. 11 (2007): 1279-301.

Geddes, Barbara. "What Do We Know About Democratization after Twenty Years?". Annual Review of Political Science 2 (1999): 115-44.

Government of Myanmar. "Prime Minister General Khin Nyunt Clarifies Future Policies and Programmes of State." 2003.

Hadenius, Axel, and Jan Teorell. "Pathways from Authoritarianism." Journal of Democracy 18, no. 1 (2007): 143-57.

Han Tha Myint. "Interview with the Author." Yangon, 2012.

Hewison, Kevin, Richard Robison, and Garry Rodan. "Political Power in Industrialising Capitalist Societies: Theoretical Approaches." In Southeast Asia in the 1990s: Authoritarianism, Democracy and Capitalism, edited by Kevin Hewison, Richard Robison and Garry Rodan, 9-40. St Leonards: Allen and Unwin, 1993.

Hla Saw. "Interview with the Author." Yangon, 2012. 
Huang, Roger Lee. "Re-Thinking Myanmar's Political Regime: Military Rule in Myanmar and Implications for Current Reforms." Contemporary Politics 19, no. 3 (2013): 247 61.

Huntington, Samuel P. The Third Wave: Democratization in the Late Twentieth Century. Norman: University of Oklahoma Press, 1993.

IMF. "World Economic and Financial Surveys." 2011.

Jessop, Bob. State Power: A Strategic-Relational Approach. Cambridge: Polity, 2008.

Jones, Lee. "The Political Economy of Myanmar's Transition." Journal of Contemporary Asia DOI: 10.1080/00472336.2013.764143 (2013).

Khin Maung Kyi, Ronald Findlay, R.M. Sundrum, Mya Maung, Myo Nyunt, and Zaw Oo. Economic Development of Burma: A Vision and a Strategy. Stockholm: Olof Palme International Center, 2000.

Khin Maung Swe. "Interview with the Author." Yangon, 2012.

Koh Kim Seng. Misunderstood Myanmar: An Introspective Study of a Southeast Asian State in Transition. Singapore: Humanities Press, 2011.

Kyaw Yin Hlaing. "Understanding Recent Political Changes in Myanmar." Contemporary Southeast Asia 34, no. 2 (2012): 197-216.

Lambrecht, Curtis. "Oxymoronic Development: The Military as Benefactor in the Border Regions of Burma." In Civilizing the Margins: Southeast Asian Government Policies for the Development of Minorities, edited by Christopher R. Duncan, 150-81. Ithaca: Cornell University Press, 2004.

MacLean, Ken. "Sovereignty in Burma after the Entrepreneurial Turn: Mosaics of Control, Commodified Spaces, and Regulated Violence in Contemporary Burma." In Taking Southeast Asia to Market: Commodities, Nature, and People in the Neoliberal Age, edited by Joseph Nevins and Nancy Lee Peluso, 140-57. Ithaca: Cornell University Press, 2008.

Marshall, Andrew R.C., and Min Zayar Oo. "Myanmar Old Guard Clings to \$8-Billion Jade Empire." Globe and Mail, 4 October 2013.

May, R.J., Stephanie Lawson, and Viberto Selochan. "Introduction: Democracy and the Military in Comparative Perspective." In The Military and Democracy in Asia and the Pacific, edited by R.J. May, Stephanie Lawson and Viberto Selochan, 1-28. Canberra: ANU E-Press, 2004.

McCoy, Alfred. The Politics of Heroin in Southeast Asia. New York: Harper \& Row, 1972.

Nordlinger, Eric A. Soldiers in Politics: Military Coups and Governments. Eaglewood Cliffs: Prentice-Hall, 1977.

O'Donnell, Guillermo, and Philippe C. Schmitter. Transitions from Authoritarian Rule: Tentative Conclusions About Uncertain Democracies. Baltimore: Johns Hopkins University Press, 1986.

Pedersen, Morten B. "The Politics of Burma's "Democratic" Transition." Critical Asian Studies 43, no. 1 (2011): 49-68.

- Promoting Human Rights in Burma: A Critique of Western Sanctions Policy. Lanham: Rowman and Littlefield, 2008.

Praeger Nyein, Susanne. "Expanding Military, Shrinking Citizenry and the New Constitution in Burma." Journal of Contemporary Asia 39, no. 4 (2009): 638-48.

Rouquié, Alain. "Demilitarization and the Institutionalization of Military-Dominated Polities in Latin America." In Transitions from Authoritarian Rule: Comparative Perspectives, edited by Guillermo O'Donnell, Philippe C. Schmitter and Laurence Whitehead, 108-36. Baltimore: Johns Hopkins University Press, 1986. 
Sadan, Mandy. "Minorities and Political Governance: The Myanmar Situation." In Minorities, Community Rights \& Political Governance: South and Southeast Asian Scenarios, edited by Lipi Ghosh, 151-79. London: Routledge, 2009.

Schedler, Andreas, ed. Electoral Authoritarianism. Boulder: Westview Press, 2006.

Selth, Andrew. Burma's Secret Military Partners. Canberra: ANU, 2000.

Skidmore, Monique. Karaoke Fascism: Burma and the Politics of Fear. Philadelphia: University of Pennsylvania Press, 2004.

Slater, Dan, and Joseph Wong. "The Strength to Concede: Ruling Parties and Democratization in Developmental Asia." Perspectives on Politics 11, no. 3 (2013): 717-33.

Smith, Martin. "Ethnic Participation and National Reconciliation in Myanmar: Challenges in a Transitional Landscape." In Myanmar's Long Road to National Reconciliation, edited by Trevor Wilson, 38-74. Singapore: ISEAS, 2006.

- State of Strife: The Dynamics of Ethnic Conflict in Burma. Washington, DC: EastWest Center, 2007.

Steinberg, David I. Burma: The State of Myanmar. Washington, DC: Georgetown University Press, 2001.

Sundhaussen, Ulf. "Military Withdrawal from Government Responsibility." Armed Forces and Society 10, no. 4 (1984): 543-62.

Svolik, Milan. The Politics of Authoritarian Rule. New York: Cambridge, 2012.

Taylor, Robert H. "Myanmar: From Army Rule to Constiutional Rule?". Asian Affairs 43, no. 2 (2012): 221-36.

- The State in Myanmar. London: Hurst, 2009.

Than Nyein. "Interview with the Author." Yangon, 2012.

Tin Maung Maung Than. "Dreams and Nightmares: State Building and Ethnic Conflict in Myanmar (Burma)." In Ethnic Conflict in Southeast Asia, edited by Kusuma Snitwongse and Scott Thompson, W., 65-108. Singapore: ISEAS, 2005.

TNI. Financing Dispossession: China's Opium Substitution Programme in Northern Burma. Amsterdam: TNI, 2011.

Tonkin, Derek. "The 1990 Elections in Myanmar: Broken Promises or a Failure of Communication?". Contemporary Southeast Asia 29, no. 1 (2007): 33-54.

UNCTAD. "Unctadstat." 2012.

US Embassy. "Burma: Jadeland Co. Supporting the Regime." Yangon, 2009.

—. "Mandalay: Diplomatic Views." Yangon, 2006.

Welch, Claude E. "Military Disengagement from Politics: Paradigms, Processes, or Random Events?". Armed Forces and Society 18, no. 3 (1992): 323-42.

Woods, Kevin. "Ceasefire Capitalism: Military-Private Partnerships, Resource Concessions and Military-State Building in the Burma-China Borderlands." Journal of Peasant Studies 38, no. 4 (2011): 747-70.

. "Conflict Timber Along the China-Burma Border: Connecting the Global Timber Consumer with Violent Extraction Sites." In Chinese Circulations: Capital, Commodities, and Networks in Southeast Asia, edited by Eric Tagliacozzo and WenChin Chang, 480-506. Durham, NC: Duke University Press, 2011.

Zöllner, Hans-Bernd. "Neither Saffron nor Revolution: A Commentated and Documented Chronology of the Monks' Demonstrations in Myanmar in 2007 and Their Background." Berlin, 2009. 